\author{
Kinga Boroń \\ Częstochowa University of Technology \\ al. Armii Krajowej 19, 42-200 Częstochowa, Poland, boron.kinga@wip.pcz.pl
}

\title{
QUALITY EVALUATION OF IRON CASTING EN-GJL-200 PRODUCED ON THE DISAMATIC LINE
}

\begin{abstract}
This article discusses the issues concerning the quality of casting surface with a small unit weight manufactured on the Disamatic automatic casting lines in a flaskless mould with a vertical parting line. The research was conducted in manufacturing conditions in one of the casting facilities in the country. The identification of casting defects for a monthly manufacturing cycle was made and agreed that the main causes of scrap casting are defects on the raw surface: lumps of moulding sand which after removal form cavities and draws as well as defects of gas origin such as blowholes. There are also defects of form namely short runs. In the later part of the work, the research results of the properties of moulding sand were presented and casting defects were selected the occurrence of which is connected with the quality of moulding sands.
\end{abstract}

\section{Key words}

grey cast iron, casting defects, sand mould

\section{Introduction}

The occurrence of casting defects or using the terminology of ISO standards of non-compliance, is directly related to the design and implementation of the production process, whose components are determined by a number of material and technological factors [1]. Depending on the cast alloy grade, the casting technology used, the casting dimensions and the degree of its complexity during production the shapes defects may be dominant, defects of the raw surface, discontinuity, internal defects and material defects classified in the PN-H83105 [2]. Although gray cast iron foundry technology on automatic DISA lines has been optimized to a very high degree, the problem of casting defects always appears and especially at the stage of implementing a new range for mass production. Proper running of the production line requires continuous control of the process parameters, which periodically undergo dynamic changes. Maintaining these parameters within strictly defined standards does not ensure complete elimination of foundry defects. The final quality of castings produced by the discussed technology depends mainly on the metallurgical quality of liquid cast iron, moulding sand properties and the course of flooding processes, solidification, cooling and knocking out mould casts [3,4]. This article focuses mainly on foundry defects, whose origin is potentially related to the quality of moulding sand and physicochemical processes occurring at the cast-form interface [5]. It should be noted that degree of lack of castings in the foundry in which the research was carried out is insignificant, which results from its high engineering level.

The processes that occur at the phase boundary between the moulding sand - casting alloys largely determine the quality of the castings. The cause of such surface defects as metal penetration, pinholes porosity, surface roughness or burn-on is the interaction of moulding sand and liquid metal [6]. In the processes running at the phase boundary, molding sand - liquid metal the gas phase plays a significant role. The quantity and composition of gases which are formed at the phase boundary between moulding sand and liquid metal have an important influence on the character of the atmosphere in the mould, which consequently leads to such defects of castings as: pinholes porosity and blowholes [5]. Casting defects are unavoidable during foundry processes and although the foundry is constantly improving the quality of its products, it is not possible to eliminate $100 \%$ of foundry defects. The aim of the research was to analyze the parameters of molding sand in relation to the quality of EN-GJL-200 cast iron castings manufactured on the Disamatic line.

\section{Materials and methods}

The tests were carried out on gray cast iron EN-GJL-200 with a unit weight not exceeding $1 \mathrm{~kg}$ and wall thickness within $20 \div 30 \mathrm{~mm}$, hereinafter referred to as Detal. The molds were made by high pressure method on Disamatic automatic casting lines in flaskless mould with a vertical dividing plane. The cast iron was smelted 
in a blast furnace with a heated blower ending with a continuous ingot casting line. Pouring moulds with liquid metal was carried out using a stopper ladle. After pouring, moulds were cooled and transported to multipurpose rumblers. After cleaning the surface of the castings, they were subjected to quality control to determine compliance with the requirements. The tests used the names specified in the PN-H-83105. The second part of the research concerned the measurement of technological properties of moulding sands. The properties such as: compression strength, permeability, moisture content, compactibility, return massmoisture content, active bentonite content in moulding sand and content of coal dust (ignition losses). The tests were carried out for refreshed moulding sand and return mass. Refresh moulding sand samples were taken from the sand bin above the moulder's automat DISA I and DISA II from three different points. However, floor sand mould samples were taken from the end of the conveyor at the sand treating plant. All tests were carried out at the Factory Laboratory on the basis of Polish standards.

Compression strength tests were carried out using the LRu device in accordance with PN-83 / H-11073. Permeability measurement was performed on the LPiR device according to the PN-80 / H-11072 standard. Moisture content tests were carried out on the basis of BN-75 / 4024-06. Compactibility tests were performed based on the BN-76 / 4024-22 standard. The content of coal dust was determined on the basis of PN-91 / H11008. The content of active clay was determined according to the BN-77 / 4024-16 standard. Samples for testing were made in accordance with PN-83 / H-11070 and PN-80/H-11073.

\section{Results}

The main cons of castings, which are repetitive in this grade of cast iron, are the following: short run casting, blowhole, lumps of moulding sand which after removal form cavities and draw. Sample images of the disclosed defects are shown in Figures 1-4.

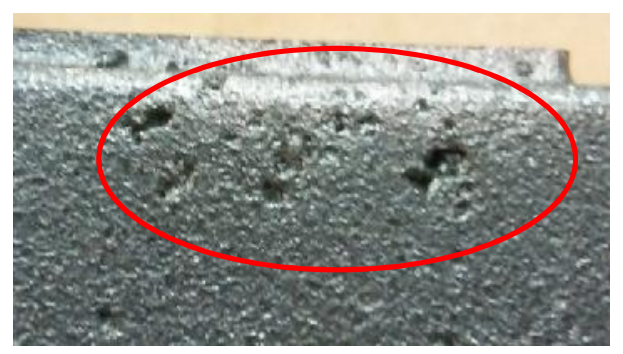

Fig. 1. Photo of a casting defect - lumps of moulding sand which after removal form cavities Source: Author's

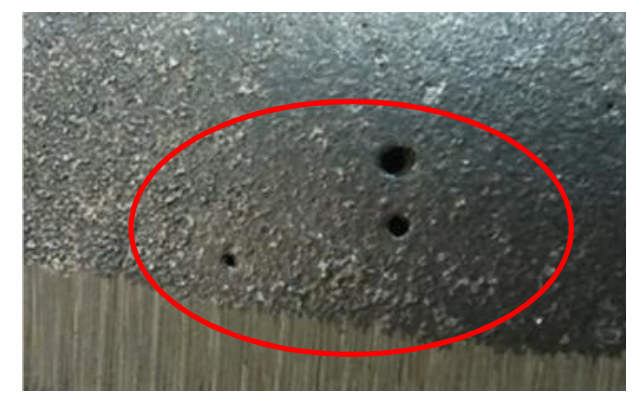

Fig.2. Photo of a casting defect - blowhole Source: Author's

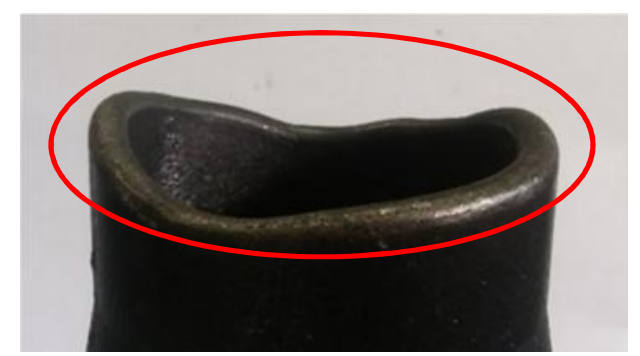

Fig. 3. Photo of a casting defect - short run casting Source: Author's 


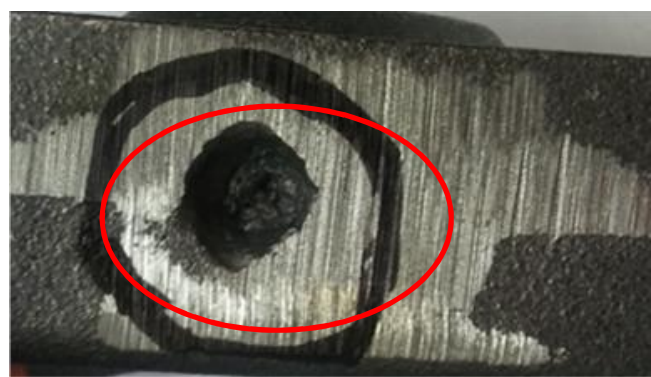

Fig. 4. Photo of a casting defect - draw Source: Author's

In the whole production range of Detal, the number of defects is less than $5 \%$ and the most significant discrepancies can be included: blowhole and lumps of moulding sand which after removal form cavities. This relationship was depicted in the graph (Fig. 5), which represents the number of non-conformities detected on 8681 manufactured Detals per month. The number of defects is low, but the foundry still tries to eliminate the causes of the emerging defects.

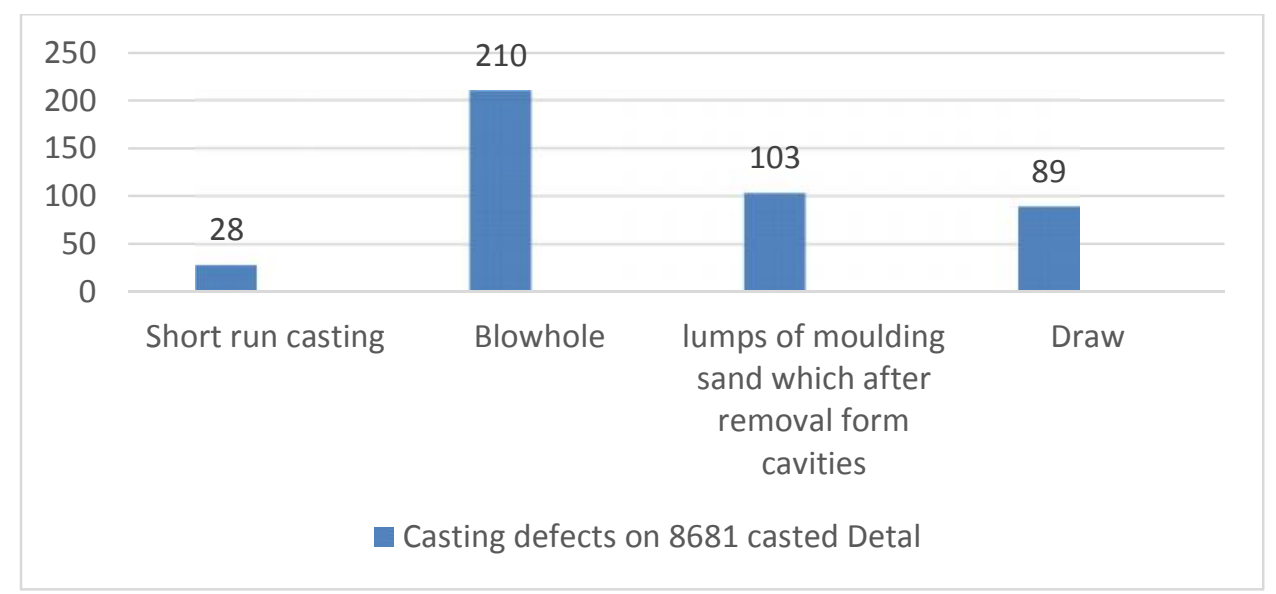

Fig. 5. Graph of the number of casting defects to the number of manufactured elements Source: Author's

In order to analyse potential causes of defects, a closer assessment of the moulding sand parameters was made. Tested moulding sand was refreshed in the speedmuller MP-090L with the following composition: $95 \%$ circulation moulding sand, $0.5 \div 1 \%$ bentonite, $3 \%$ fresh moulding sand and $2.5 \%$ water. The moulding sand tests were carried out on the same day as the Detal casting and the results are presented in Table 1.

Table 1. Parameters of moulding sand - average values

\begin{tabular}{|c|c|c|c|c|c|}
\hline 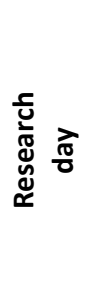 & 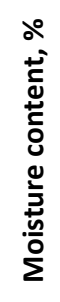 & 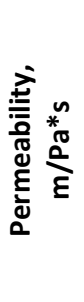 & 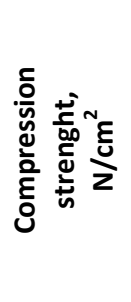 & 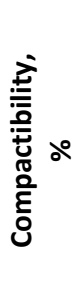 & 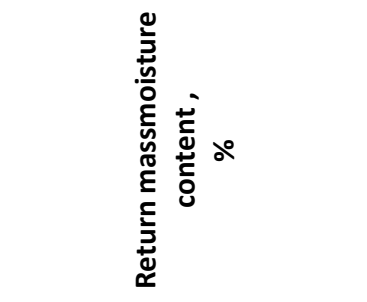 \\
\hline 1 & 2,7 & 280 & 18,50 & 42 & $\begin{array}{c}\text { Input of the return mass:0,2 } \\
\text { Return mass output:0,4 }\end{array}$ \\
\hline 2 & 2,9 & 260 & 19,83 & 42 & $\begin{array}{c}\text { Input of the return mass:0,6 } \\
\text { Return mass output:0,7 }\end{array}$ \\
\hline 3 & 3,0 & 260 & 19,50 & 35 & $\begin{array}{l}\text { Input of the return mass:0,6 } \\
\text { Return mass output:0,6 }\end{array}$ \\
\hline 4 & 3,0 & 250 & 19,63 & 44 & $\begin{array}{l}\text { Input of the return mass:0,8 } \\
\text { Return mass output:0,7 }\end{array}$ \\
\hline
\end{tabular}


Moisture content test results were close to the optimal value, approx. $3 \%$ however, the worrying result is themoisture content of the return mass, which is too low. The optimum return mass parameters for this type of casting should be in the range of $1-1.5 \%$. Nevertheless, the results of compactibility are within limits but they are too close to the upper limit of the standard, which may have a bearing on the quality of the castings. Fig. 6 . shows the averaged contents of active clay and coal dust in the moulding sand in the subsequent production days of Detal.

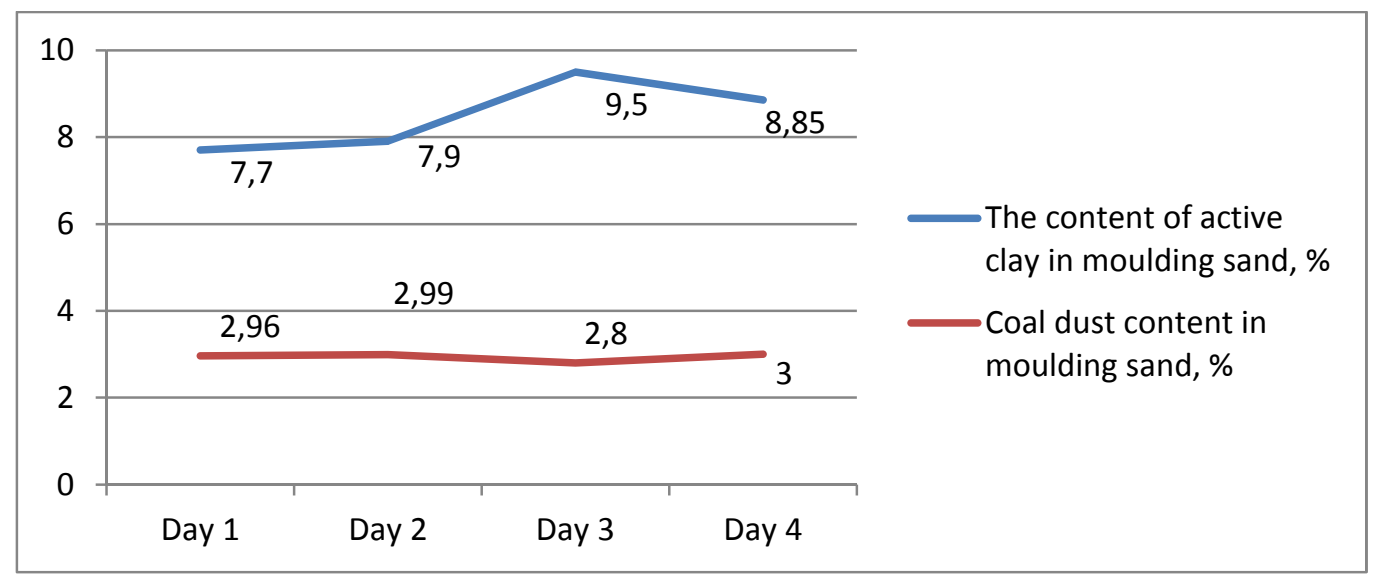

Fig. 6. Graph of change in the content of active clay and coal dust in moulding sand Source: Author's

Coal dust added to the moulding sands ensures the smoothness of the casting surface and also prevents scorching of the mass into the casting. Such properties have dust from hard coal from which, when the mould pouring temperature is increased, bright coal is released. The requirements for coal dust are included in the PN-91 / H-11008 and present the following contents: water $<2.0 \%$, volatile matter: $30 \div 40 \%$, ash $<4.0 \%$, sulfur $<0.8 \%$, bright coal $>9.0 \%[7,8]$. After analysing the graph, it appears that the content of coal dust in the tested moulding mass remains at the level of $3 \%$ and falls within the permissible range of $2.0 \div 4.5 \%$.

The content of active clay is of significant importance to obtain a mould with the desired strength. Pouring liquid metal into the mould several times deactivates part of the bentonite, which may be the result of inactive dust formation, which in turn leads to a deterioration of moulding sand properties [9]. The graph shows that the content of active clay is $\sim 9 \%$ and this result is too high compared to the optimal overall values of $7-8 \%$. However, the foundry in which the tests were carried out achieves the appropriate quality of casting with such a content of active clay.

The tests showed, that the average values of the technological parameters of the moulding sand are generally within the permissible limits of the relevant standards, the only exception is the test results for return mass moisture content. Despite all efforts, there are recurring foundry defects in the castings, the causes of which may be related to local mass heterogeneity, overheating of some areas of the mold cavity, as well as physicochemical interactions at the contact area mould and cast, during the cooling process and solidification of casting. The high pouring temperature, often technologically necessary, results in rapid burning of coal dust and is the reason for the inferior surface quality of the castings. As a result of its interaction, the deactivation of bentonite is also faster and therefore it is necessary to intensively refresh the moulding sand. In contact with liquid metal the carrier of bright coal decomposes. In a perfect condition, the bright coal in a crystalline form with a high degree of disintegration and dispersion is released. This is accompanied by a reductive atmosphere. The carbon is disengaged to form a coating on all, even physico-chemically inactive surfaces of the mould cavity and core surfaces. Excessive burning of coal dust on the upper surfaces of the mould cavity, as well as in the areas of the heat centres of the casting, unfortunately creates a danger of founding defects of gas origin. The source of blowholes revealed in the studies may also be: air trapped in the mould during pouring into moulds caused by turbulence during the metal flowing through the pouring- gate and air suction into the cavity of the mould, as well as insufficient de-aeration of the mould, too strong moulding sand compactibility, gases emitted from the core after pouring the mould - improper proportions of resins used to make the cores and too much moisture in the mould. Other reasons may be pouring into mould from too great a height or the inadequate pouring temperature of the mould. Draw is caused by the contraction of metal alloys during cooling and solidification. This defect is most often created in the areas of heat centres of the casting and this is often 
caused by too high a pouring temperature of the mould. Short run casting arises as a result of: a too low pouring temperature, the wrong way of mould pouring, too small / large stream or pouring with breaks, too little metal in the ladle, an inadequate permeability. Lumps of moulding sand which after removal, form cavities can also be formed by burning a mould or core, which is caused by a small amount of coal dust in the moulding sand, as well as during folding and the step drift of mould packages on the production line.

\section{Conclusions}

After the tests were carried out, the occurrence of repeated casting defects was observed despite the properties of moulding sand that were within the norms. The main non-conformities when casting gray iron cast products include: short run casting, blowholes, lumps of moulding sand which after removal, form cavities and draw. After the analysis, it appears that the most frequently occurring discrepancies are: blowholes and lumps of moulding sand which after removal form cavities. In the case of an external blowhole, the causes are gases trapped in the mould. This may be due to insufficient de-aeration of the mould or too much densified moulding sand, which is reflected in the results.

The lumps of moulding sand which after removal form cavities can be caused by the wrong relation between the amount of bentonite and the amount of water and also by the low moisture content of the return mass, which can be supported by the results for this parameter.

\section{References}

[1] PN-EN 1561/2012 Odlewnictwo-Żeliwo szare

[2] PN-85/H-83105 Odlewy - Podział i terminologia wad

[3] Lewandowski J.L., 1997, Tworzywa na formy odlewnicze, Wydawnictwo Akapit, Kraków

[4] Kościówko H., Wyrwicki R., 1996, Metodyka badań materiałów ilastych, Państwowy Instytut Geologiczny Warszawa, Wrocław

[5] Holtzer M, Zych J., 1997, Zjawiska zachodzące na granicy faz masa formierska-ciekłe żeliwo a jakość powierzchni odlewów, Krzepnięcie Metali i Stopów, nr 33

[6] Holtzer M., Przegląd Odlewnictwa, 1994, nr 6, 2014-217

[7] Lewandowski J.L., Solarski W., Zawada J., Toksyczność masy formierskiej z bentonitem zawierającej pyl węglowy, Krzepnięcie Metali i Stopów, Nr 35, 1998 PAN- Oddział Katowice PL-ISSN 0208-9386

[8] PN-91/H-11008 Odlewnicze materiały formierskie- pył węglowy

[9] Michta-Stawiarska T., 1998, Trudności w stabilizacji właściwości klasycznych mas formierskich, Krzepnięcie Metali i Stopów, Nr 35, P AN - Oddział Katowice PL. ISSN 0208-9386 